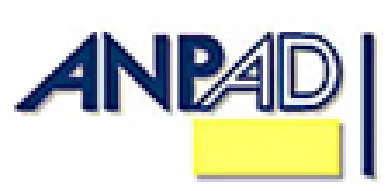

Available online at http://www.anpad.org.br/bar

BAR, Rio de Janeiro, v. 9, n. 1, art. 5, pp. 88-109, Jan./Mar. 2012

\title{
Discretionary-Based Disclosure: Evidence from the Brazilian Market
}

Fernando Dal-Ri Murcia *

E-mail address: murcia@usp.br Universidade de São Paulo - USP São Paulo, SP, Brazil.

Ariovaldo dos Santos E-mail address: arisanto@usp.br Universidade de São Paulo - USP São Paulo, SP, Brazil.

* Corresponding author: Fernando Dal-Ri Murcia

Rua Osvaldo Dixon, 77, Codesg, Guarantiguetá, SP, 12500-000, Brazil.

Copyright (C) 2012 Brazilian Administration Review. All rights reserved, including rights for translation. Parts of this work may be quoted without prior knowledge on the condition that the source is identified. 


\begin{abstract}
The primary objective of this paper is to identify the factors that explain Brazilian companies' level of voluntary disclosure. Underpinning this work is the Discretionary-based Disclosure theory. The sample is composed of the top 100 largest non-financial companies listed in the Bolsa de Valores de São Paulo (Brazilian Securities, Commodities, and Futures exchange - BOVESPA). Information was gathered from Financial Statements for the years ending in 2006, 2007, and 2008, with the use of content analysis. A disclosure framework based on 27 studies from these years was created, with a total of 92 voluntary items divided into two dimensions: economic (43) and socio-environmental (49). Based on the existing literature, a total of 12 hypotheses were elaborated and tested using a panel data approach. Results evidence that: (a) Sector and Origin of Control are statistically significant in all three models tested: economic, socio-environmental, and total; (b) 'Profitability' is relevant in the economic model and in the total model; (c) Tobin's Q is relevant in the socio-environmental model and in the total disclosure model; (d) Leverage and Auditing Firm are only relevant in the economic disclosure model; (e) Size, Governance, Stock Issuing, Growth Opportunities and Concentration of Control are not statistically significant in any of the three models.
\end{abstract}

Key words: discretionary disclosure; determinants; Brazil. 


\section{Introduction}

Voluntary disclosure is any disclosure that exceeds what is recommended by law and represents a freely made decision by managers to disclose additional information (Meek, Roberts, \& Gray, 1995). In this sense, voluntary disclose is a choice, just like other accounting choices regarding recognition and measurement of economic transactions (for instance FIFO or LIFO for inventory). But why would managers and/or companies choose to disclose more information than required by law?

Recent studies have showed that companies enjoy several benefits with increased disclosure, for instance: lower cost of equity capital (Alencar, 2007; Botosan, 1997; Hail, 2002), lower cost of debt (Lima, 2007; Sengupta, 1998), greater market liquidity (Leuz \& Verrecchia, 2000; Welker, 1995) and more analyst following (Healy, Hunton, \& Palepu, 1999; Lang \& Lundholm, 2000).

However, if companies do not disclose all the information they have, i.e. they are not fully transparent, one should presume that there are costs involved with voluntary disclosure, for example costs related to personnel and certification (Leuz \& Wysocki, 2008) and property costs, both in regards to the disclosure of information that is strategic to the company (Verrecchia, 2001).

In this scenario, managers possess different kinds of information of which disclosure is not mandatory and they exercise discretion with regard to the information about which they have knowledge (Verrecchia, 2001). The rationale is that costs and benefits influence the choice of engaging in voluntary disclosure.

In this environment, characterized by costs and benefits, Discretionary-based Disclosure (Verrecchia, 2001) provides the conceptual and theoretical framework which can be used to examine the incentives that motivate voluntary disclosure. This theory evaluates under which circumstances companies will choose to disclose certain kinds of information. Therefore, voluntary disclosure can be explained by corporate characteristics such as size, profitability, leverage etc. (Cunha \& Ribeiro, 2006).

Prior works on the determinants of voluntary disclosure have been conducted in several countries: France (Depoers, 2000); Hong Kong (Wallace \& Naser, 1995), Japan (Cooke, 1992), Malaysia (Hossain, Tan, \& Adams, 1994), the Czech Republic (Patton \& Zelenka, 1997), Sweden (Cooke, 1989) and Switzerland (Raffounier, 1995).

In that same line of thinking, the objective of this paper is to identify the factors that explain the level of voluntary disclosure of Brazilian listed companies.

The main justifications for conducting this research are: (a) Brazil is a BRIC, the largest economy in South America and one of the largest economies in the World and (b) the Brazilian Market is characterized by low enforcement, incentives for manipulation of financial statements due to tax influence, an unstable financial market and poor governance standards (Lopes \& Walker, 2008) where a great variability of disclosure level is expected. For these reasons, Brazil represents a unique scenario for an empirical test of the determinants of voluntary disclosure.

At the same time, this paper extends the existing literature in two different manners. First, most of the prior studies have analyzed only one dimension of disclosure (for instance only socioenvironmental information). On the other hand, this paper uses a disclosure index based on 27 prior studies and composed of 92 kinds of information that take into consideration social, environmental, and economic dimensions. This is important because factors (profitability, for example) that explain certain dimensions of disclosure might not explain others. This paper takes this fact into consideration and tests for the different dimensions of disclosure separately.

Also, most prior studies have analyzed corporate disclosure in only one period, using a cross sectional approach. This might be a problem because some variables (size, for example) may be 
significant when we compare different companies in one period (larger companies disclose more information than smaller companies, for instance), but insignificant when we compare the company to itself along the years (a company has grown, but disclosure has remained constant). For that reason, we analyzed corporate disclosure during three years with a panel data approach which takes both cross sectional and longitudinal aspects into consideration.

The remainder of this paper is organized as follow: the next section presents this study's hypotheses and reviews Discretionary-based Disclosure; following the methodological aspects are described; after that, the study's results; the last section presents this paper's conclusions.

\section{Hypotheses Development}

The theory underpinning this study is that of Discretionary-based Disclosure, which treats disclosure endogenously, by considering managers' incentive to disclose certain kinds of information. According to Dye (2001) this is a special case of Game Theory, where the central premise is that entities will always evaluate the information to be disclosed as a function of costs and benefits.

The rationale is that the benefits of voluntary disclosure should be higher than its costs (Dye, 2001). Basically, if the managers' objective is to maximize shareholders' wealth, there seems to be selective disclosure; where information that favors an entity is disclosed, while any that harms it is not (Verrecchia, 2001).

Given Game Theory analysis, it can be expected that much of the voluntary disclosure is beneficial to the entity (Dye, 2001). However, due to the risk of adverse selection derived from information asymmetry, entities may also disclose negative information whenever they believe there will be a higher penalty for the absence of certain information. This is because there are costs of being evaluated by the market as a lemon (Akerlof, 1970).

According to Dobler (2005), Discretionary-based Disclosure analyzes the conditions in which information is voluntary disclosed by companies due to its strategic interaction with external agents (investors, competitors etc.). In this sense, this theory helps to identify in which circumstances managers and/or companies choose to disclose (or not to disclose) information. Hence, voluntary disclosure could be explained by characteristics related to the company.

In this paper, 12 factors have been extracted from existing literature in order to explain the level of voluntary disclosure of Brazilian companies. Figure 1 illustrates the research design.

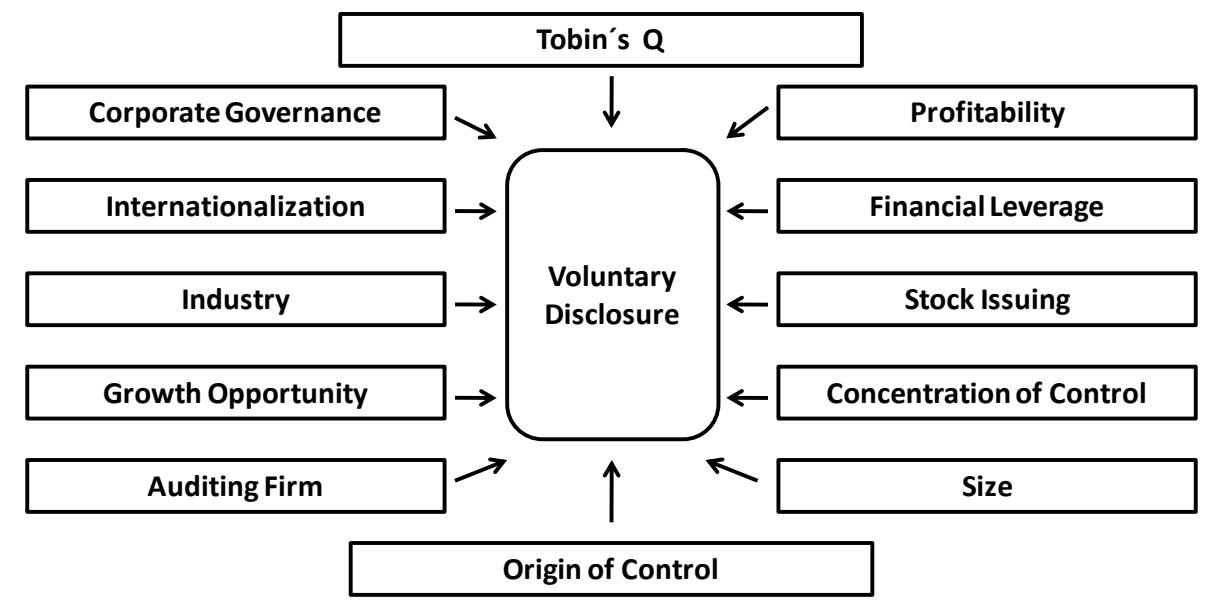

Figure 1. Research Design - Determinants of Voluntary Disclosure. 
The 12 factors presented in Exhibit 1 are this study's hypotheses: (a) auditing firm; (b) profitability; (c) Tobin's Q; (d) internationalization; (e) size; (f) corporate governance; (g) financial leverage; (h) concentration of control; (i) stock issuing; (j) growth opportunity; (k) sector and (l) origin of control. A brief discussion of these hypotheses are presented below.

H1: Companies audited by 'Big Four' firms tend to disclose more information than companies audited by 'other auditing firms'.

Watts and Zimmerman (1986) argue that auditors incur costs when entering into contracts with clients. In this sense, auditors tend to influence companies to disclose as much information is possible in order to reduce possible litigation costs due to an absence of information. The fraud scandal involving auditing company Arthur Andersen and its client, Enron Corporation, illustrates the fact that, in some cases, auditors might be considered liable for their clients' practices. In this sense, we expect companies audited by KPMG, PricewaterhouseCoopers, Deloitte Touche Tohmatsu and Ernst\&Young to disclose more information than companies audited by other auditing firms.

H2: Companies with higher levels of profitability tend to disclose more information than companies with lower levels of profitability.

H3: Companies with better performance in the financial market tend to disclose more information than companies with worse performance in the financial market.

Without information investors cannot differentiate good companies from bad companies (lemons). Therefore, due to information asymmetry they tend to offer a price (average price between good and bad companies) that is not attractive to good companies. This argument is based on the problem of adverse selection derived from information asymmetry, which was first presented by Akerlof (1970).

In this scenario, disclosure reduces information asymmetry and serves as a signal of the company's quality. This is known as Signaling Theory. Therefore, well-run companies have incentives to distinguish themselves from less profitable companies in order to raise capital on the best available terms. Thus, we expect more profitable firms and firms with better performance in the financial market to disclose more information in order to differentiate themselves from lemons.

H4: Companies listed in the New York Stock Market (NYSE) tend to disclose more information than companies listed only in Bolsa de Valores de São Paulo (BOVESPA).

According to Archambault and Archambault (2003), disclosure practice tends to be influenced by the stock market in which the company operates. Also, companies listed in international financial markets have more pressure to disclose information when compared to companies that negotiate only in the local market (Meek et al., 1995).

Specifically in the United States, the requirements for disclosing information are much more demanding than in Brazil. Also, the enforcement of these requirements by the Securities Exchange Commission (SEC) is much stricter than the enforcement exercised by the Brazilian Exchange Commission. Both of these factors should lead to greater transparency. Thus, we expect Brazilian companies listed in the New York Stock Market (NYSE) to disclose more information in the Brazilian Market as well.

H5: Larger companies tend to disclose more information than smaller companies.

The development of this hypothesis is based on the Political Cost Hypothesis of Positive Accounting Theory (Watts \& Zimmerman, 1986). Basically, larger firms have higher political costs due to their visibility which might lead to higher scrutiny from both government and society. According to Hackston and Milne (1996), both Agency Theory and Legitimacy Theory also contain arguments for a size-disclosure relationship. In addition, Firth (1979) suggests that companies with higher visibility tend to disclose more information in order to improve corporate image. 
H6: Companies with better corporate governance practices tend to disclose more information than companies with worse corporate governance practices.

According to the Bonding Hypothesis, companies from countries with weak institutions, characterized by low investor protection, might engage in additional governance mechanisms in order to gain investors' confidence (Leuz, 2006). Specifically in Brazil, companies might list their stocks in the Corporate Governance Levels of Bovespa.

We expected companies with better corporate governance practices to have better disclosure practices as well. This is because corporate disclosure can be considered one dimension of corporate governance due to the fact that its monitoring function can reduce the risk of expropriation by managers.

H7: Companies with higher levels of financial leverage tend to disclose more information than companies with lower levels of financial leverage.

Due to manager's natural tendency to assume higher risks, creditors might impose restrictions on a company's operation, such as with debt covenants. This is due to risk that the money borrowed by the company might be transferred to shareholders. According to Depoers (2000), the larger the proportion of debt in the company's capital structure, the higher the agency costs, and consequently more possibilities of wealth transfer from creditors to investors. In this sense, Agency Theory states that firms with higher levels of financial leverage tend to voluntary disclose more information in order to satisfy creditors and remove the suspicions of wealth transfer to shareholders (Jensen \& Meckling, 1976).

H8: Companies that have less concentrated ownership tend to disclose more information than companies with more concentrated ownership.

The more dispersed the firm's ownership is, the greater the separation between property and control, which generates larger agency conflicts between insiders and outsiders (Depoers, 2000), and consequently has a direct influence on the level of disclosure (Chow \& Wong-Boren, 1987). The premise is that investors who have a significant portion of company's stocks can obtain information privately (Archambault \& Archambault, 2003), because they are generally part of the management or the Board, and thus have insider information. In this sense, we expect companies with more disperse ownership to disclose more information.

H9: Companies that issued stock in 2007, 2008 and 2009 tend to disclose more information than companies that did not issue stock in that period.

According to Baums (2002), companies would be willing to disclose information when raising capital even if they were not required to do so. In this sense, even if disclosure wasn't mandatory, companies would still disclose information. That happens because companies that are able to reduce information asymmetry during the time they are issuing stock should be able to enjoy lower levels of the cost of capital (Lang \& Lundholm, 2000).

In this sense, we expect companies that underwent a stock issuance during the years of 2007, 2008 and 2009 (i.e., ex post, the year following the disclosure) to voluntary disclosure more information in order to reduce the information asymmetry component of cost of capital.

H10: Companies with greater growth opportunities tend to disclose more information than companies with lower growth opportunities.

Companies that have greater opportunities to grow are likely to need resources in the near future. In this sense, these companies tend to adopt better corporate governance mechanisms, for instance better disclosure practices (Khancel, 2007). More transparency results in better investor protection due to enhanced monitoring and better decision making. Consequently investors would be 
more willing to finance companies. Therefore, we expect companies that have greater growth opportunities to disclose more information.

H11: Companies from the electric energy sector tend to disclose more information than companies from other sectors.

Some sectors are more regulated than others. Regulation, in theory, should increase disclosure, as good laws are the ones that can be enforced. That is true, especially, in a developing country like Brazil, where empirical evidence has shown that companies don't follow the disclosure requirement of international accounting standards (see for instance Murcia \& Santos, 2009, on financial instruments disclosure).

Specifically in the electric energy sector, regulation and enforcement from Agência Nacional de Energia Elétrica (ANEEL) has largely influenced the disclosure habits of companies. For instance, although is not mandatory, most companies from this sector do disclose their Social Balance. Also, specifically regarding social information, descriptive analysis has shown that eight out of the ten companies with the highest levels of social disclosure are from the electric energy sector. For these reasons, we expect companies from the electric energy sector to disclose, on average, more information than companies from other sectors.

H12: Companies controlled by the State tend to disclose more information than companies with private control.

The justification to why a company controlled by the state should disclose higher levels of information is not clear, as studies on the determinants of disclosure have not tested this hypothesis. Hence, there is not a descriptive theory that justifies this hypothesis.

However, descriptive analysis of data has shown that origin of control might be a significant variable in explaining a company's voluntary disclosure level. For instance, descriptive analysis has shown that five out of the ten companies with highest levels of disclosure are controlled by the State (Petrobras, Sabesp, Sanepar, Cesp and Eletrobrás). For this reason, the effect of origin of control is taken into consideration and therefore we expect companies controlled by the State to disclose more information.

\section{Methods}

The presentation of this study's methods is divided into three parts: (a) analysis of corporate voluntary disclosure, (b) description of the study's sample and (c) the panel data model.

\section{Analysis of corporate voluntary disclosure}

Content analysis was utilized in order to collect information and analyze corporate disclosure, According to Krippendorf (1990), this technique enables the study of messages in a rigorous and systematic manner. Also, content analysis permits a researcher to classify qualitative information into categories (Abbott \& Monsen, 1979), which facilitates the inference process of messages (Bardin, 1977).

A very important decision regarding content analysis regards which document to analyze. In this study, financial statements, for the years ending in 2006, 2007, and 2008, and available on Bovespa's website were selected for analysis. In this sense, the documents analyzed in this study were the Demonstração Financeira Padronizada (DFPs), which are the official versions of a company's financial statement in Brazil. 
In order to analyze voluntary corporate disclosure, an index was elaborated. This index is based on 27 prior studies regarding corporate disclosure: Ernst \& Ernst (1978); Chow and Wong Boren (1987); Zeghal and Ahmed (1990); Meek, Roberts and Gray (1995); Gray, Kouhy and Lavers (1995); Hackston and Milne (1996); Burrit and Welch (1997); Botosan (1997); Williams (1999); Depoers (2000); Salomone and Galluccio (2001); Deegan, Rankin and Tobin (2002); Hail (2002); Nossa (2002); Standard \& Poor's (2002); Kuasirikun and Sherer (2004); Lanzana (2004); Yusoff, Lehman and Nasir (2006); Malacrida and Yamamoto (2006); Lima (2007); Alencar (2007); Iudícibus, Martins and Gelbcke (2007); Andrade and Salotti (2008); Francis, Nanda and Olsson (2008); Hossain (2008), Morris and Tronnes (2008) and Orens and Lybaert (2008).

This index contains only information that is not mandatory for Brazilian listed companies. It has a total of 92 types of information and is divided into two dimensions: socio-environmental (49) and economic (34). The socio-environmental dimension has 11 categories and 49 subcategories: social financial information (4), products and services (2), employees (9), environmental policies (5), environmental management and auditing (3), impact of products and services on the environment (7), energy (3), environmental financial information (6), environmental education and research (2), carbon credits (4) and other environmental information (4).

Table 1

\section{Disclosure Index - Social-Environmental Dimension}

\begin{tabular}{ll}
\hline SOCIAL DISCLOSURE \\
\hline Social Financial Information & Mentions of the value added or distributed \\
& Social investments \\
& Expenditures on social projects \\
& Statement about the adequacy of safety regulations \\
Products and Services & Complaints about the company's products and services \\
& Number of employees \\
& Employee salary \\
& Employee benefits \\
& Employee satisfaction \\
& Minorities in the workforce \\
Education and training & Safety in the workplace \\
Accidents in the workplace & Relationship with labor unions \\
\hline
\end{tabular}

ENVIRONMENTAL DISCLOSURE

Actual environmental policies

Environmental goals, targets and objectives

Environmental Policies

Compliance with licenses, laws and environmental entities

Environmental partnerships

Environmental prizes and participation and sustainability indexes 
Table 1 (continued)

\section{ENVIRONMENTAL DISCLOSURE}

\begin{tabular}{|c|c|}
\hline \multirow{3}{*}{$\begin{array}{l}\text { Environmental Management and } \\
\text { Auditing }\end{array}$} & Environmental management \\
\hline & ISO 14.000 \\
\hline & Environmental auditing \\
\hline \multirow{7}{*}{$\begin{array}{l}\text { Impact of Products and Services in the } \\
\text { Environment }\end{array}$} & Waste \\
\hline & Packaging \\
\hline & Recycling \\
\hline & Development of ecological products \\
\hline & Efficient use of water \\
\hline & Impacts on the environment \\
\hline & Repair of environmental damages \\
\hline \multirow{3}{*}{ Energy } & Energy conservation / energy efficiency in business operations \\
\hline & Use of waste material for energy production \\
\hline & Development of new sources of energy \\
\hline \multirow{6}{*}{ Environmental Financial Information } & Environmental investments \\
\hline & Environmental costs and expenses \\
\hline & Environmental liabilities \\
\hline & Description of accounting practices for environmental issues \\
\hline & Environmental insurance \\
\hline & Environmental assets \\
\hline \multirow{2}{*}{$\begin{array}{l}\text { Environmental Education and } \\
\text { Research }\end{array}$} & Environmental education \\
\hline & Environmental research \\
\hline \multirow{4}{*}{ Carbon Credits } & Clean development mechanisms (CDM) \\
\hline & Carbon credits \\
\hline & Emission of greenhouse gases \\
\hline & Certified emission reductions (CERs) \\
\hline \multirow{4}{*}{ Other Environmental Information } & Any mention concerning sustainability \\
\hline & Forest management \\
\hline & Biodiversity conservation \\
\hline & Stakeholders \\
\hline
\end{tabular}

The economic dimension of the disclosure index has 6 categories and 34 subcategories: business environment (8), operating activity (8), strategic information (8), financial information (7), financial ratios (4) and corporate governance (8). 
Table 2

\section{Disclosure Index - Economic Dimension}

\begin{tabular}{|c|c|}
\hline & ECONOMIC DISCLOSURE \\
\hline \multirow{8}{*}{ Business Environment } & Impact of economic events on the company \\
\hline & Discussion of sector (industry) \\
\hline & Discussion of competitors \\
\hline & Relationship with suppliers \\
\hline & Customer satisfaction \\
\hline & Market share \\
\hline & Identification of key business risks \\
\hline & Foreign exchange rate exposure \\
\hline \multirow{8}{*}{ Operating Activity } & Company's history \\
\hline & Organizational structure \\
\hline & Technological aspects of operations \\
\hline & Segment information \\
\hline & Use of operating capacity \\
\hline & Efficiency indicators \\
\hline & Units produced or services rendered \\
\hline & Units sold \\
\hline \multirow{8}{*}{ Strategic Information } & Company's goals and objectives \\
\hline & Future capital expenditures \\
\hline & Main business markets \\
\hline & New markets to enter \\
\hline & Politics for reinvesting earnings \\
\hline & Research and development \\
\hline & Quality of products and services \\
\hline & Price of products and services \\
\hline \multirow{7}{*}{ Financial Information } & Price level accounting \\
\hline & Information in US GAAP or IFRS \\
\hline & Detailed information on company's costs and expenses \\
\hline & Stock price or appreciation \\
\hline & Market capitalization \\
\hline & Projections (cash flow, earnings, revenues, etc.) \\
\hline & Cash flow statement \\
\hline \multirow{4}{*}{ Financial Ratios } & Profitability ratios \\
\hline & Liquidity ratios \\
\hline & Financial leverage ratios \\
\hline & EBITDA \\
\hline
\end{tabular}


Table 2 (Continued)

\begin{tabular}{ll}
\hline \multicolumn{1}{c}{ ECONOMIC DISCLOSURE } \\
\hline Main corporate governance practices \\
Members of fiscal board \\
Members of board of administration \\
Corporate Governance & Managers' compensation \\
& Auditors' compensation \\
& Main shareholders \\
& Relationship with investors \\
\hline
\end{tabular}

It is worthwhile to mention that the disclosure index has been adjusted for the fiscal year ending in 2008 due to the enactment of Law 11.638/07 that required Brazilian companies to disclose the Cash Flow Statement and Value Added Statement starting from the year 2008. Hence, both of these statements were only considered in the years ending in 2006 and 2007, as the objective of the disclosure index was to evaluate only voluntary information.

Based on the framework presented in Exhibits 2 and 3, three disclosure indexes were computed for each company: (a) socio-environmental disclosure, (b) economic disclosure and (c) total disclosure (socio-environmental and economic). These disclosure indexes utilized a non-weighted approach (1 if the company disclosed the information and 0 otherwise). In this sense, a company's disclosure score is computed by dividing the number of subcategories disclosed by the total number of categories.

For instance, Petrobras, from the Oil and Gas sector, for the year ending in 2006, received: (a) an economic disclosure score of $81,40 \%$ (35/43), (b) a socio-environmental disclosure score of $73.47 \%$ (36/49) and (c) a total disclosure score of 77,17\% (71/92). Based on these criteria, three disclosure indexes were assigned to each company in each one of the three years.

In order to check the internal validity of the disclosure index, the Crombach's Alpha test was conducted. The results were: 0,9010 or $90,10 \%$ in $2006,0,9113$ or $91,13 \%$ in 2007 and 0,8960 or $89,60 \%$ in 2008 . Scores around $90 \%$ are considered very good. In this sense, the disclosure index developed in this study was considered appropriate to be used as a dependent variable in the models that wished to explain voluntary disclosure practices of Brazilian companies.

\section{Study's sample}

The sample was composed of the largest companies listed in the Bolsa de Valores de São Paulo (Bovespa). The top one hundred companies based on gross revenues of 2007 were selected, excluding the financial industry due to their specificities. However, 2 financial statements in 2006 and 8 financial statements in 2008 were not available due to delay, cancellation, etc. Hence, the final sample comprised: 98 companies in 2006, 100 companies in 2007 and 92 companies in 2008.

In terms of market capitalization, companies in the sample represent approximately 55,07\% (2006), 57,11\% (2007) and 55,91\% (2008) of total market capitalization of Bovespa. In this sense, although the sample was not selected randomly, it can be considered representative of Brazilian listed companies. 


\section{Panel data approach}

The reason for using a panel data approach in this paper derives from analyzing corporate voluntary disclosure during three years, as this statistical technique takes both cross sectional (100 companies) and longitudinal (years ended in 2006, 2007 and 2008) aspects into consideration.

In this paper, because voluntary disclosure was divided into two dimensions, three models for disclosure were tested for: (a) socio-environmental disclosure, (b) economic disclosure and (c) total disclosure (socio-environmental and economic). The disclosure index for each model is the dependent variable.

Table 3

\section{Dependent Variables of the Panel Model}

\begin{tabular}{|c|c|c|}
\hline $\begin{array}{c}\text { Dependent } \\
\text { Variables }\end{array}$ & Symbol & Proxies Developed \\
\hline $\begin{array}{l}\text { Social and } \\
\text { Environmenta } \\
1 \text { Disclosure }\end{array}$ & DIS_SOC_ENV & $\begin{array}{l}\text { Number of subcategories regarding social and environmental disclosure } \\
\text { presented by the company (x) divided by the total number of } \\
\text { subcategories in the index regarding social and environmental disclosure } \\
\text { (49) }\end{array}$ \\
\hline $\begin{array}{l}\text { Economic } \\
\text { Disclosure }\end{array}$ & DIS_ECO & $\begin{array}{l}\text { Number of subcategories regarding economic disclosure presented by } \\
\text { the company (y) divided by the total number of subcategories in the } \\
\text { index regarding economic disclosure ( } 43 \text { ) }\end{array}$ \\
\hline $\begin{array}{l}\text { Total } \\
\text { Disclosure }\end{array}$ & DIS_TOTAL & $\begin{array}{l}\text { Total number of subcategories presented by the company }(x+y) \text { divided } \\
\text { by the total number of subcategories in the index }(92)\end{array}$ \\
\hline
\end{tabular}

On the other hand, the independent variables are the 12 hypotheses being tested: (a) auditing firm; (b); profitability; (c) Tobin's Q (d); internationalization; (e) size; (f) corporate governance; (g) financial leverage; (h) concentration of control; (i) stock issuing; (j) growth opportunity; (k) sector (industry) and (1) origin of control.

Table 4 illustrates the independent variables of this study.

Table 4

Independent Variables of Panel Model

\begin{tabular}{|c|c|c|c|}
\hline $\begin{array}{l}\text { Independent } \\
\text { Variables }\end{array}$ & Symbol & $\begin{array}{l}\text { Expected } \\
\text { Relation }\end{array}$ & Proxies Used \\
\hline Size & SIZE & $(+)$ & Ln (Revenues) \\
\hline Sector & SECTOR & $(+)$ & $\begin{array}{l}\text { Companies that belong to the electric sector }=1 \text { and } \\
\text { companies from other sectors }=0\end{array}$ \\
\hline Tobin's Q & TOBIN & $(+)$ & (Market Capitalization + Book Liabilities)/ Book Assets \\
\hline Origin of control & $\begin{array}{l}\text { ORIG_CONT } \\
\mathrm{R}\end{array}$ & $(+)$ & $\begin{array}{l}\text { Companies controlled by the State }=1 \text { and }=0 \\
\text { otherwise }\end{array}$ \\
\hline Profitability & PROFIT & $(+)$ & Return on Equity (ROE) \\
\hline Financial leverage & LEV & $(+)$ & Total Liability divided by Total Assets \\
\hline $\begin{array}{l}\text { Corporate } \\
\text { governance }\end{array}$ & GOV & $(+)$ & $\begin{array}{l}\text { Companies that belong to Level I, II and New Market of } \\
\text { Bovespa }=1 \text { and }=0 \text { otherwise }\end{array}$ \\
\hline
\end{tabular}


Table 4 (Continued)

\begin{tabular}{|c|c|c|c|}
\hline $\begin{array}{l}\text { Independent } \\
\text { Variables }\end{array}$ & Symbol & $\begin{array}{l}\text { Expected } \\
\text { Relation }\end{array}$ & Proxies Used \\
\hline Stock issuing & ISSUE & $(+)$ & $\begin{array}{l}\text { Companies that issued stock during the years of } 2007 \text {, } \\
2008 \text { and } 2009=1 \text { and otherwise }=0\end{array}$ \\
\hline $\begin{array}{l}\text { Growth } \\
\text { opportunity }\end{array}$ & GROW & $(+)$ & Revenue change from $\mathrm{t}$ e $\mathrm{t}_{-1}$. \\
\hline $\begin{array}{l}\text { Concentration of } \\
\text { control }\end{array}$ & $\begin{array}{l}\text { CONC_CON } \\
\mathrm{T}\end{array}$ & $(+)$ & $\begin{array}{l}\text { Companies controlled by a single stockholder }(50 \%+1 \\
\text { of ordinary shares })=1 \text { otherwise }=0 .\end{array}$ \\
\hline Auditing firm & AUD & $(+)$ & $\begin{array}{l}\text { Companies audited by 'Big Four' }=1 \text { and companies } \\
\text { audited by 'other companies' }=0 .\end{array}$ \\
\hline Internationalization & INTER & $(+)$ & Companies with ADRs Levels II e III $=1$ otherwise $=0$. \\
\hline
\end{tabular}

One important decision when using a panel data approach regards which type of panel model to use: pooling, fixed effects and random effects. For these, statistical tests have been conducted: Chow Test (pooling versus fixed effects), Breusch-Pagan (pooling versus random effects) and Hausman Test (random effects versus fixed effects). The results, which are presented in exhibit 6, showed the panel data with random effects is the most appropriate one for all three disclosure models of this study.

Table 5

Statistical Tests - Panel Data Model

\begin{tabular}{llll}
\hline \multirow{2}{*}{ Tests } & \multicolumn{3}{c}{ Disclosure Dimensions } \\
\cline { 2 - 4 } & \multicolumn{1}{c}{ Economic } & \multicolumn{1}{c}{ Socio -Environmental } & \multicolumn{1}{c}{ Total } \\
\hline Chow & Prob $>\mathrm{F}=0.0000$ & Prob $>\mathrm{F}=0.0000$ & Prob $>\mathrm{F}=0.0000$ \\
Breusch-Pagan & Prob $>$ chi2 $=0.0000$ & Prob $>$ chi $2=0.0000$ & Prob $>$ chi $2=0.0000$ \\
Hausman & Prob $>$ chi $2=0.5549$ & Prob $>$ chi $2=0.9067$ & Prob $>$ chi $2=0.7311$ \\
$\begin{array}{l}\text { Panel data model to be } \\
\text { used }\end{array}$ & Random Effects & Random Effects & Random Effects \\
\hline
\end{tabular}

\section{Results}

This section presents the results of the panel data analysis with the objective to identify the factors that are relevant in explaining voluntary corporate disclosure in the Brazilian financial market. The results are presented for the three disclosure models: economic, socio-environmental and total (economic and socio-environmental). Initially, in order to identify possible indications of multicollinearity, a correlation matrix analysis has been conducted. 
Table 6

\section{Correlation Matrix}

\begin{tabular}{|c|c|c|c|c|c|c|c|c|c|c|c|c|c|c|c|c|c|}
\hline & 宗 & 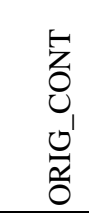 & D & 号 & 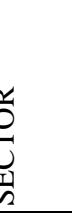 & 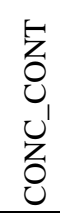 & & $\frac{\underline{r}}{\underline{y}}$ & $\underset{\sim}{\stackrel{N}{V}}$ & $\begin{array}{l}\sum_{1} \\
\text { I } \\
\bigcup^{\prime} \\
0 \\
n_{1} \\
\tilde{n}^{\prime}\end{array}$ & 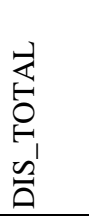 & 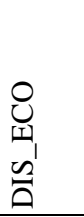 & 贫 & $\begin{array}{l}Z \\
\stackrel{Z}{0} \\
\stackrel{0}{\sigma}\end{array}$ & $\begin{array}{l}3 \\
0 \\
\text { 先 }\end{array}$ & 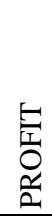 & $\begin{array}{l}\omega \\
\tilde{\Omega} \\
\tilde{\Omega}\end{array}$ \\
\hline AUD & 1 & & & & & & & & & & & & & & & & \\
\hline ORIG_CONT & $-0,17$ & 71 & & & & & & & & & & & & & & & \\
\hline GOV & 0,09 & 0,02 & 1 & & & & & & & & & & & & & & \\
\hline SECTOR & $-0,12$ & 20,10 & $-0,0$ & $07 \quad 1$ & & & & & & & & & & & & & \\
\hline CONC_CONT & 0,12 & $-0,14$ & $\begin{array}{ll}4 & 0,18\end{array}$ & &, 261 & 1 & & & & & & & & & & & \\
\hline INTER & 0,15 & 0,09 & 0,15 & &, 180 & 0,07 & 1 & & & & & & & & & & \\
\hline SIZE & 0,07 & 0,22 & 0,10 & &, $06-$ & $-0,0$ & $01 \quad \mathbf{0 , 5}$ & 56 & 1 & & & & & & & & \\
\hline DIS_SOC-ENV & 0,01 & 0,40 & $-0,0$ & $05 \quad 0,4$ & 45 & $-0,1$ & $19 \quad 0,1$ & 13 & $0,17 \quad 1$ & 1 & & & & & & & \\
\hline DIS_TOTAL & 0,06 & 0,39 & 0,01 & 0,36 & $-0,1$ & 110 & 0,20 & 0,22 & 0,93 & 1 & & & & & & & \\
\hline DIS_ECO & 0,12 & 0,27 & 0,10 & 0,15 & 0,03 & & 0,26 & 0,25 & 0,59 & 0,85 & 1 & & & & & & \\
\hline LEV & $-0,07$ & $-0,16$ & $-0,17$ & 0,03 & 0,0 & & 0,03 & 0,01 & $-0,15$ & $5-0,15$ & $-0,10$ & 1 & & & & & \\
\hline TOBIN & 0,20 & $-0,24$ & 0,21 & $-0,17$ & $7 \quad 0,19$ & & 0,14 & 0,06 & $5-0,01$ & $1-0,01$ & $-0,01$ & $-0,06$ & 1 & & & & \\
\hline GROW & $-0,02$ & $-0,07$ & 0,17 & $-0,28$ & 30,08 & & 0,04 & 0,04 & $-0,26$ & $6-0,23$ & $3-0,13$ & 0,01 & 0,18 & 1 & & & \\
\hline PROFIT & 0,21 & $-0,22$ & $-0,01$ & $-0,01$ & 10,10 & & $-0,01$ & 0,04 & $-0,01$ & 10,03 & 0,08 & 0,29 & 0,42 & 0,13 & 1 & & \\
\hline ISSUE & 0,01 & $-0,01$ & 0,10 & $-0,07$ & $7 \quad 0,02$ & & $-0,01$ & 0,03 & $-0,07$ & $7-0,04$ & 0,01 & 0,11 & 0,06 & 0,05 & 0,17 & 1 & \\
\hline
\end{tabular}

It should be noted that the variables internationalization and size have a correlation coefficient of 0,56. This seems natural, as the proxy used for internationalization is issuance of ADRs Levels II and III in the NYSE. Therefore, as expected, Brazilian companies listed in the NYSE that issue these types of receipts are large corporations. Consequently, these two variables have a strong, positive correlation.

This strong correlation indicates possible signals of multicollinearity, which was confirmed when both of these variables were included in the models. The inclusion of internationalization in the models caused the polarity of variable size to change, from positive to negative, contrary to that stated by the existing literature (Political Cost Hypothesis for instance), as larger companies tend to disclose, on average, more information. Therefore, internationalization was subsequently excluded from the analysis.

The other independent variables did not present strong correlations with each other. On the other hand, as expected, dependent variables did present strong, positive correlations with each other. That seems natural, as companies who disclose more economic information tend to also disclose more social and environmental information. However, dependent variables are not perfectly correlated. In this sense, the research design of this paper is justified, i.e., the factors that explain socioenvironmental disclosure are not the same factors that explain economic disclosure. Hence, the disclosure dimensions need to be analyzed separately. 
The results from the panel data analysis are presented as follows. First, the economic disclosure model is presented; second, the socio-environmental model; and last, the total disclosure model.

Table 7

Panel Data - Economic Disclosure (DIS_ECO)

\begin{tabular}{lllll}
\hline Variable & Coefficient & Std. Error & t statistics & Prob. \\
\hline SIZE & 0.017837 & 0.030219 & 0.590281 & 0.5556 \\
SECTOR & 0.066646 & 0.034381 & 1.938451 & 0.0539 \\
TOBIN & 0.017161 & 0.014000 & 1.225793 & 0.2216 \\
ORIG_CONT & 0.184635 & 0.054321 & 3.398985 & 0.0008 \\
PROFIT & 0.014328 & 0.004901 & 2.923199 & 0.0038 \\
LEV & 0.009981 & 0.003116 & 3.202771 & 0.0016 \\
GOV & 0.013016 & 0.018880 & 0.689384 & 0.4913 \\
ISSUE & -0.021212 & 0.013223 & -1.604090 & 0.1102 \\
GROW & -0.010865 & 0.007353 & -1.477627 & 0.1410 \\
CONC_CONT & 0.022475 & 0.021971 & 1.022945 & 0.3075 \\
AUD & 0.019049 & 0.010513 & 1.811989 & 0.0714 \\
C & 0.104374 & 0.428170 & 0.243767 & 0.8076 \\
R-square & 0.111721 & Adj. R-square & 0.066485 & \\
F Statistics & 2.469717 & Prob. (F) & 0.006240 & \\
Jarque-Bera & 1.967629 & Prob. (JB) & 0.373882 & \\
Durbin-Watson & 2.370170 & & & \\
\hline
\end{tabular}

Note. * White cross-section standard errors \& covariance (d.f. corrected).

Regarding the panel data assumptions: (a) Jarque-Bera test did not reject the null hypothesis of normal distribution of errors; (b) Durbin-Watson statistics is 2,37, which is a little above of the 1,8-2,2 range, indicating possible residual autocorrelation and; (c) heteroscedasticity has been detected and corrected by the White covariance matrix.

The model is significant as a whole, according to the $\mathrm{F}$ statistics. Its explanatory power, measured by R-square and Adjusted R-square, is approximately 11,17\% and 6,65\% respectively. Sector, Origin of Control, Profitability and Leverage are statistically significant at a significance level of 5\%. Auditing is also significant, but at a $10 \%$ significance level. Concerning the expected direction of the relations, Growth Opportunity was the only metric variable that presented a different polarity from what was expected. 
Table 8

Panel Data - Socio-Environmental Disclosure (DIS_SOC_ENV)

\begin{tabular}{lllll}
\hline Variable & Coefficient & Std. Error & t statistics & Prob. \\
\hline SIZE & 0.007813 & 0.034390 & 0.227200 & 0.8205 \\
SECTOR & 0.167514 & 0.023718 & 7.062702 & 0.0000 \\
TOBIN & 0.042033 & 0.006473 & 6.493868 & 0.0000 \\
PROFIT & 0.011460 & 0.011627 & 0.985611 & 0.3254 \\
ORIG_CONT & 0.321167 & 0.079839 & 4.022683 & 0.0001 \\
LEV & 0.010847 & 0.018181 & 0.596587 & 0.5514 \\
GOV & -0.028773 & 0.025448 & -1.130675 & 0.2594 \\
ISSUE & -0.023724 & 0.052385 & -0.452871 & 0.6511 \\
GROW & -0.016781 & 0.011154 & -1.504431 & 0.1339 \\
CONC_CONT & -0.017035 & 0.024169 & -0.704828 & 0.4817 \\
AUD & 0.014084 & 0.032129 & 0.438372 & 0.6616 \\
C & 0.120091 & 0.464205 & 0.258704 & 0.7961 \\
R-square & 0.280176 & Adj. R-square & 0.243518 & \\
F Statistics & 7.643016 & Prob. (F) & 0.000000 & \\
Jarque-Bera & 1.132726 & Prob. (JB) & & 0.567586 \\
Durbin-Watson & 2.078771 & & & \\
\hline
\end{tabular}

Note. * White cross-section standard errors \& covariance (d.f. corrected).

The socio-environmental disclosure model is also significant as a whole according to the $\mathrm{F}$ statistics and has an explanatory power of approximately 28,02\% (R-square) and 24,35\% (Adjusted Rsquare). Concerning panel data assumptions, residuals: (a) are normally distributed according to the Jarque-Bera test; (b) not autocorrelated according to the Durbin-Watson test; and (c) do not present constant variance, which has been corrected by White covariance matrix.

Only three independent variables were statistically significant at a 5\% significance level: Sector, Tobin's Q and Origin of Control. It is worth mentioning that Growth Opportunity, which had a marginal significance (0.1339), once more presented a negative angular coefficient.

Finally, the total disclosure model is also statistically significant and has an explanatory power of around $21,91 \%$ (R-square) and 17,94\% (Adjusted R-square). Once more, heteroscedasticity was detected and corrected by the White covariance matrix.

In this model, three variables were statistically significant at a $5 \%$ significance level: Sector, Tobin's Q and Origin of Control. Profitability is also significant, but at a 10\% significance level. 
Table 9 illustrates the total disclosure model.

Table 9

Panel Data - Total Disclosure (DIS_TOTAL)

\begin{tabular}{lllll}
\hline Variable & Coefficient & Std. Error & t statistics & Prob. \\
\hline SIZE & 0.012712 & 0.034236 & 0.371303 & 0.7108 \\
SECTOR & 0.120333 & 0.028184 & 4.269559 & 0.0000 \\
ORIG_CONT & 0.257698 & 0.070624 & 3.648890 & 0.0003 \\
TOBIN & 0.030317 & 0.008931 & 3.394400 & 0.0008 \\
PROFIT & 0.012272 & 0.006752 & 1.817636 & 0.0705 \\
LEV & 0.012197 & 0.009112 & 1.338459 & 0.1822 \\
GOV & -0.009946 & 0.022082 & -0.450404 & 0.6529 \\
ISSUE & -0.022517 & 0.030239 & -0.744653 & 0.4573 \\
GROW & -0.013481 & 0.009622 & -1.401112 & 0.1626 \\
CONC_CONT & 0.001370 & 0.021526 & 0.063649 & 0.9493 \\
AUD & 0.016402 & 0.021959 & 0.746947 & 0.4559 \\
C & 0.109576 & 0.472926 & 0.231699 & 0.8170 \\
R-square & 0.219164 & Adj. R-square & 0.179399 & \\
F Statistics & 5.511503 & Prob. (F) & 0.000000 & \\
Jarque-Bera & 2.629376 & Prob. (JB) & 0.268558 & \\
Durbin-Watson & 2.289731 & & & \\
\hline
\end{tabular}

Note. *White cross-section standard errors \& covariance (d.f. corrected).

Based on the results, presented in Tables 7, 8 and 9, it is possible to summarize this study's main findings. At the same time, it is also possible to compare the main findings with what was expected from the hypotheses, as extracted from existing literature. Table 10 presents a summary of the determinants of voluntary disclosure. 
Table 10

Determinants of Voluntary Disclosure - Summary of Findings

\begin{tabular}{cccccccc}
\hline \multirow{2}{*}{ Variables } & Expected & \multicolumn{2}{c}{$\begin{array}{c}\text { Economic } \\
\text { Disclosure }\end{array}$} & Signal & $\begin{array}{c}\text { Social - Environmental } \\
\text { Disclosure }\end{array}$ & \multicolumn{2}{c}{$\begin{array}{c}\text { Total } \\
\text { Disclosure }\end{array}$} \\
\cline { 3 - 8 } & & $\begin{array}{c}\text { Observed } \\
\text { Signal }\end{array}$ & Sig & $\begin{array}{c}\text { Observed } \\
\text { Signal }\end{array}$ & Sig & $\begin{array}{c}\text { Observed } \\
\text { Signal }\end{array}$ & Sig \\
\hline SIZE & $(+)$ & $(+)$ & No & $(+)$ & No & $(+)$ & No \\
SECTOR & $(+)$ & $(+)$ & Yes* & $(+)$ & Yes* & $(+)$ & Yes* \\
TOBIN & $(+)$ & $(+)$ & No & $(+)$ & Yes* & $(+)$ & Yes* \\
ORIG_CONT & $(+)$ & $(+)$ & Yes* & $(+)$ & Yes* & $(+)$ & Yes* \\
PROFIT & $(+)$ & $(+)$ & Yes* & $(+)$ & No & $(+)$ & Yes** \\
LEV & $(+)$ & $(+)$ & Yes* & $(+)$ & No & $(+)$ & No \\
GOV & $(+)$ & $(+)$ & No & $(-)$ & No & $(-)$ & No \\
ISSUE & $(+)$ & $(-)$ & No & $(-)$ & No & $(-)$ & No \\
GROW & $(+)$ & $(-)$ & No & $(-)$ & No & $(-)$ & No \\
CONC_CONT & $(+)$ & $(+)$ & No & $(-)$ & No & $(+)$ & No \\
AUD & $(+)$ & $(+)$ & Yes** & $(+)$ & No & $(+)$ & No \\
INTER & $(+)$ & \multicolumn{7}{c}{ Excluded from the Models due to multicollinearity } & \\
\hline
\end{tabular}

Note. *Significance level of $5 \%$; **Significance level of $10 \%$.

\section{Conclusions}

This paper used Discretionary-based Disclosure (Verrecchia, 2001) as the underpinning theory and aimed to identify the factors that explain the level of voluntary disclosure of Brazilian listed companies. For these, a panel data approach was used, where the level of voluntary disclosure (economic, socio-environmental and total) was explained by 12 independent variables, which were the study's hypotheses. Main findings were:

. Sector and Origin of Control are statistically significant in all three models of disclosure;

- Profitability is statistically significant in the economic model and in the total model;

- Tobin's Q is statistically significant in the social and environment model and in the total disclosure model;

- Leverage and Auditing are statistically significant only in the economic model;

- Size, Corporate Governance, Growth Opportunity are not statistically significant in any of the models of disclosure;

- Observed signals of angular coefficient are as expected from the existing literature, except for growth opportunity that presented a negative relation with voluntary disclosure.

- Corporate Governance, Concentration of Control and Stock Issuing also presented different signals. 
However, because they are binary variables and were not statistically significant, further interpretation is not possible.

Interpretations of these findings indicate that ANEEL, which is the regulating entity of the electric sector, does influence the level of corporate voluntary disclosure. Apparently, this seems to be unique to the Brazilian Market, as the existing literature has not mentioned anything on this matter regarding other countries.

At the same time, it is worthwhile mentioning the fact that companies controlled by the state have, on average, better disclosure practices than companies with private control. That also seems to be unique to the Brazilian Market, where the State still controls some corporations, especially in the Public Utilities sector. Surprisingly enough, findings demonstrate that these companies are more transparent than others. However, theoretical interpretation of that result is not found in the existing literature, as prior studies have not tested this hypothesis.

Finally, the fact that profitability and Tobin's Q were significant in explaining voluntary disclosure practices corroborate Discretionary-based Disclosure as findings have shown that "good" quality Brazilian companies disclose more information. Apparently they do that in order to differentiate themselves and avoid the risk of being evaluated by the market as a "lemon".

\section{Received 27 April 2010; received in revised form 20 September 2010.}

\section{References}

Abbott, W., \& Monsen, J. (1979). On the measurement of corporate social responsibility: self-reported disclosures as a method of measuring corporate social environment. Academy of Management Journal, 22(3), 501-515. doi: 10.2307/255740

Akerlof, G. (1970). The market for 'lemons': quality uncertainty and the market mechanism. Quarterly Journal of Economics, 84(3), 488-500. doi: 10.2307/1879431

Alencar, R. (2007). Nível de disclosure e custo de capital próprio no mercado Brasileiro (Doctoral dissertation). Universidade de São Paulo, São Paulo, SP, Brazil.

Andrade, J., \& Salloti, B. (2008, June). Balanço de recursos humanos: uma análise de companhias do mercado brasileiro. Proceedings of the Congresso da Associação Nacional dos Programas de pós-Graduação em Ciências Contábeis, Salvador, BA, Brazil, 2.

Archambault, J., \& Archambault, M. (2003). A multinational test of determinants of corporate disclosure. International Journal of Accounting, 38(2), 173-194. doi: 10.1016/S00207063(03)00021-9

Bardin, L. (1977). Análise de conteúdo. Lisboa: Edições 70.

Baums, T. (2002). Changing patterns of corporate disclosure in continental Europe: the example of Germany [Law Working Paper No. 004/2002]. European Corporate Governance Institute (EGCI), Bruxelas, Bélgica.

Botosan, C. (1997). Disclosure level and cost of equity capital. The Accounting Review, 72(3), 323349. doi: $10.1002 /$ mde. 1256

Burrit, R., \& Welch, S. (1997). Accountability for environmental performance of the Australian Commonwealth public sector. Accounting, Auditing \& Accountability Journal, 10(4), 532-561. doi: 10.1108/09513579710367494 
Chow, C. W., \& Wong-Boren, A. (1987). Voluntarily financial disclosure by Mexican corporations. The Accounting Review, 62(3), 533-541.

Cooke, T. E. (1989). Disclosure in the corporate annual reports of Swedish companies. Accounting and Business Research, 19(74), 113-124.

Cooke, T. E. (1992). The impact of size, stock market listing and industry type on disclosure in the annual reports of Japanese listed corporations. Accounting and Business Research, 22(87), 229237.

Cunha, J. V. A., \& Ribeiro, M. (2006, September). Divulgação voluntária de informações de natureza social: um estudo nas empresas brasileiras. Anais do Encontro Nacional da Associação Nacional de Pós-Graduação e Pesquisa em Administração, Salvador, BA, Brazil, 30.

Deegan, C., Ranking, M., \& Tobin, J. (2002). An examination of the corporate social and environmental disclosures of BHP from 1983-1997: a test of legitimacy theory. Accounting, Auditing and Accountability Journal, 15(3), 312-43. doi: 10.1108/09513570210435861

Depoers, F. (2000). A cost benefit study of voluntary disclosure: some empirical evidence from French listed companies. European Accounting Review, 9(2), 245-263. doi: $10.1080 / 09638180050129891$

Dobler, M. (2005). How informative is risk reporting? A review of disclosure models [Munich Business Research Working Paper No 2005-01]. Dresden University of Technology, Faculty of Economics and Business Management, Dresden, Germany.

Dye, R. A. (2001). An evaluation of 'essays on disclosure' and the disclosure literature in accounting. Journal of Accounting and Economics, 32(1-3), 181-235. doi:10.1016/S0165-4101(01)00024-6

Ernst \& Ernst. (Eds.). (1978). Social responsibility disclosure: 1978 survey. Cleveland, OH: Author.

Firth, M. A. (1979). The impact of size, stock market listing, and auditors on voluntary disclosure in corporate annual reports. Accounting and Business Research, 9(36), 273-280.

Francis, J., Nanda, D., \& Olson, P. (2008). Voluntary disclosure, earnings quality, and cost of capital. Journal of Accounting Research, 46(1), 53-99. doi: 10.1111/j.1475-679X.2008.00267.x

Gray, R., Rouhy, R., \& Lavers, S. (1995). Constructing a research database of social and environmental reporting by UK companies. Accounting, Auditing and Accountability Journal, 8(2), 78-101. doi: 10.1108/09513579510086812

Hackston, D., \& Milne, M. (1996). Some determinants of social and environmental disclosure in New Zealand companies. Accounting, Auditing and Accountability Journal, 9(1), 77-108. doi: $10.1108 / 09513579610109987$

Hail, L. (2002). The impact of voluntarily corporate disclosure on the ex-ante cost of capital for Swiss firms. European Accounting Review, 11(4), 741-773. doi: 10.1080/0963818022000001109

Healy, P., Huntton, A., \& Palepu, K. (1999). Stock performance and intermediation changes surrounding sustained increases in disclosure. Contemporary Accounting Research, 16(3), 485520. doi: 10.1111/j.1911-3846.1999.tb00592.x

Hossain, M. (2008, August). The extent of disclosure in annual reports of banking companies: the case of India. Proceedings of the American Accounting Association Annual Meeting, Anaheim, CA, USA, 11. 
Hossain, M., Tan, L., \& Adams, M. (1994). Voluntary disclosure in an emerging capital market: Some empirical evidence from companies listed in the Kuala Lumpur stock exchange. The International Journal of Accounting, 29(3), 334-351.

Iudícibus, S., Martins, E., \& Gelbke, E. (2007). Manual de contabilidade das sociedades por ações (7th ed.). São Paulo: Editora Atlas.

Jensen, M., \& Meckling, W. (1976). Theory of firm: managerial behavior, agency costs and ownership structure. Journal of Financial Economics, 3(4), 305-360. doi: 10.2139/ssrn.94043

Khancel, I. (2007). Corporate governance: measurement and determinant analysis. Managerial Auditing Journal, 22(8), 740-760. doi: 10.1108/02686900710819625

Krippendorf, K. (1990). Metodología de análisis de contenido: teoría y práctica. Barcelona: Paidós Comunicación.

Kuasirikun, N., \& Sherer, M. (2004). Corporate social accounting in Thailand. Accounting, Auditing and Accountability Journal, 17(4), 629-660. doi: 10.1108/09513570410554588

Lang, M., \& Lundholm, R. (2000). Voluntary disclosure and equity offerings: reducing information asymmetry or hyping the stock. Comtemporary Accounting Research, 17(4), 623-662. doi: 10.1506/9N45-F0JX-AXVW-LBWJ

Lanzana, A. (2004). Relação entre o disclosure e governança corporativa das empresas brasileiras (Master's thesis). Universidade de São Paulo, São Paulo, SP, Brazil.

Leuz, C. (2006). Cross listing, bonding and firms reporting incentives: a discussion of Lang, Raedy and Wilson. Journal of Accounting and Economics, 42(1-2), 285-299. doi: 10.1016/j.jacceco.2006.04.003

Leuz, C., \& Verrecchia, R. (2000). The economic consequences of increased disclosure. Journal of Accounting Research, 38(Suppl.), 91-124.

Leuz, C., \& Wysocki, P. (2008). Economic consequences of financial reporting and disclosure regulation: a review and suggestions for future research [Working Paper]. Social Science Research Network, Chicago, IL, USA. Retrieved August 22, 2008, from http://papers.ssrn.com/sol3/papers.cfm?abstract_id=1105398

Lima, F. (2007). Utilização da teoria da divulgação para avaliação da relação do nível de disclosure com o custo da dívida das empresas brasileira (Doctoral dissertation). Universidade de São Paulo, São Paulo, SP, Brazil.

Lopes, A., \& Walker, M. (2008, August). Firm-level incentives and the informativeness of accounting reports: an experiment in Brazil. Proceedings of the American Accounting Association Annual Meeting, Anaheim, CA, USA, 11.

Malacrida, M. J. C., \& Yamamoto, M. M. (2006). Governança corporativa: nível de evidenciação das informações e sua relação com a volatilidade das ações do IBOVESPA. Revista Contabilidade \& Finanças, (Edição Comemorativa) 17, 65-79. Retrieved from http://www.scielo.br/pdf/rcf/v17nspe/v17nspea06.pdf. doi.org/10.1590/S151970772006000400006

Meek, G., Roberts, C., \& Gray, S. (1995). Factors influencing voluntarily annual report disclosure by U.S., U.K., and continental European multinational corporations. Journal of International Business Studies, 26(3), 555-572. doi: 10.1057/palgrave.jibs.8490186 
Morris R., \& Tronnes, P. (2008, August). The determinants of voluntary strategy disclosure: an international comparison. Proceedings of the American Accounting Association Annual Meeting, Anaheim, CA, USA, 11.

Nossa, V. (2002). Disclosure ambiental: uma análise do conteúdo dos relatórios ambientais de empresas do setor de papel e celulose em nível internacional (doctoral dissertation). Universidade de São Paulo, São Paulo, SP, Brazil.

Orens, R., \& Lybaert, N. (2008, April). Analysts' earnings forecasts and non-financial disclosures. Proceedings of the European Accounting Association Annual Congress, Rotterdam, Netherlands, 31 .

Patton, J., \& Zelenka, I. (1997). An empirical analysis of the determination of the extent disclosure in annual reports of joint stock companies in the Czech Republic. The European Accounting Review, 6(4), 605-626. doi: 10.1080/09638189700000003

Raffournier, B. (1995). The determinants of voluntary disclosure by Swiss listed companies. European Accounting Review, 4(2), 261-280. doi: 10.1080/09638189500000016

Salomone, R., \& Galluccio, G. (2001). Environmental issues and financial reporting trends: a survey in the chemical and oil \& gas industries [FEEM Working Paper $\mathrm{N}^{\circ}$ 32]. Fondazione Eni Enrico Mattei, Milano, Italy.

Sengupta, P. (1998). Corporate disclosure quality and the cost of debt. The Accounting Review, 73(4), 459-474.

Standards \& Poor's. (2002). Transparency and disclosure (T\&D) 2002 rankings. Standard and Poor's, New York, NY, USA. Retrieved September 15, 2008, from http://www.standardandpoors.com/

Verrecchia, R. E. (2001). Essays on disclosure. Journal of Accounting and Economics, 32(1-3), 97180.

Wallace, O., \& Naser, K. (1995). Firm specific determinants of the comprehensiveness of mandatory disclosure in the corporate annual reports of firms listed on the stock exchange of Hong Kong. Journal of Accounting and Public Policy, 14(4), 311-368.

Watts, R., \& Zimmerman, J. (1986). Positive accounting theory. Englewood Cliffs, NJ: Prentice Hall.

Welker, M. (1995). Disclosure policy, information asymmetry, and liquidity in equity markets. Contemporary Accounting Research, 11(2), 801-827. doi: 10.1111/j.1911-3846.1995.tb00467.x

Williams, M. (1999). Voluntary environmental and social accounting disclosure practices in the AsiaPacific region: an international empirical test of political economy theory. The International Journal of Accounting, 34(2), 209-238. doi: 10.1016/S0020-7063(99)00006-0

Yusoff, H., Lehman, G., \& Nasir, N. (2006) Environmental engagements through the lens of disclosure practices: a Malaysian story. Asian Review of Accounting, 14(1-2), 122-148. doi: $10.1108 / 13217340610729509$

Zeghal, D., \& Ahmed, S. (1990). Comparison of social responsibility information disclosure media used by Canadian firms. Accounting, Auditing and Accountability Journal, 3(1), 1-13. doi: $10.1108 / 09513579010136343$ 